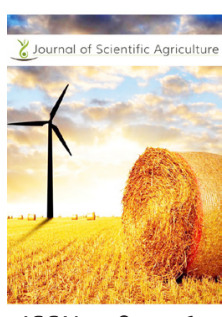

ISSN: $2184^{-0261}$

Received: January 18, 2019

Accepted: March 20, 2019

Published: March 26, 2019

*Corresponding Author:

A. A. Sanusi

Email: sasogo2016@outlook.com KEYWORDS: Gibberellic acid, cucumber, growth, yield

\section{Effect of seed presoaking in gibberellic acid on growth, flowering, and yield of cucumber (Cucumis sativus L.) plants}

\author{
A. A. Sanusi \\ Department of Plant Production, Faculty of Agriculture, University of Sirte, Libya
}

\begin{abstract}
A field experiment was carried out in the region of Serti, Libya follows completely randomized design with five replicate to evaluate the potential of seed presoaking in different concentrations of gibberellins $(0,5 \mu \mathrm{g} / \mathrm{ml}, 10 \mu \mathrm{g} / \mathrm{ml} \mathrm{and} 20 \mu \mathrm{g} / \mathrm{ml})$ on cucumber growth, flowering, and yield. Application of gibberellin $\left(\mathrm{GA}_{3}\right)$ significantly increased epicotyls length, and plant height $(\mathrm{cm})$ during flowering and at the end of the experimental period compared to the control plants. Moreover, application of $\mathrm{GA}_{3}$ concentration inducing flowering decreased staminate flower number and increased pistillate flower number. Additionally, the promotive effect of GA3 concentration on plant growth and flowering attributes was accompanied byincreased yield and its components. The treatment of $10 \mu \mathrm{g} / \mathrm{ml} \mathrm{GA}$ can be used to increase growth and vield attributes in cucumber.
\end{abstract}

\section{INTRODUCTION}

Cucumber (Cucumissativus L., Cucurbitaceae) is one of the most important, popular and gainful vegetable plants worldwide. The fruits are extremely nutritive and have very high moisture(95\%), extremely small calories (about 15 calories per cup), rich in minerals and vitamins. They contain an elevated quantity of many phytochemicals and antioxidants, among other trace elements [1]. Cucumber is used in folk medicine for many diseases [2]. Also, cucumber has been used as skin protector [3]. Besides their cooling impact on skin, cucumber slices present a lot of profit to the eyes [4]. Now a day, it is broadly used to manufacture different cosmetics interns as face cream and shampoo etc. Cucumber exhibits an attractive variety of floral morphology. Similarly, flower maleness considerably decrease the fruit yield [5]. Adjacent to the maleness problem, cucumber production, particularly throughout late summer, faces numerous problems, including low fruit setting that will affect the yield and the quality [6].

In current years, growth regulating substances (GRS) has been applied in many plants to manipulate the growth and yield. GRS acting a vital function to adjust morpho-physiological aspects of the crops. They should be applied in best concentrations, stage of use, species specificity, seasons etc $[5,7,8]$. Along with the GRS, gibberellic acid $\left(\mathrm{GA}_{3}\right)$ is identified as environmental signals which persuade numerous developmental processes in crops, as seed germination, stem elongation, flowering induction, and fruit set establishment in addition to declining leaf chlorosis [5,8-11]. Furthermore, $\mathrm{GA}_{3}$ has the larger significance of sex alteration in different cucurbitaceous plants $[5,8,12]$. The low concentration of $\mathrm{GA}_{3}$ usually delayed the appearance of the first staminate flower and enhances the initiation of pistillate flower $[5,8,13]$. Although, the $\mathrm{GA}_{3}$ has to be judiciously designed in terms of precise concentration and stage of application that comprise the main impediments in $\mathrm{GA}_{3}$ applicability. Keeping this view, the current study was undertaken to assess the role of $\mathrm{GA}_{3}$ concentration on rising cucumber plant growth, flowering and yield.

\section{MATERIALS AND METHODS}

The current study was done at the private farm in Sirte city, Libya during 2013 season. The field experiment was laid out in a completely randomized design with four treatments, i.e., 0 , 5, 10 , and $20 \mu \mathrm{g} / \mathrm{ml} \mathrm{GA}_{3}$. The treatments were replicated fifth in experimental design. The soil of the experimental plot was sandy loam with moderate fertility.

The seed of Bata Alpha cultivar of cucumber was disinfected by soaking in ethanol $70 \%$ for $5 \mathrm{~min}$., then washed three times with distilled water, and, then divided into four groups, for soaking treatments. The sterilized seeds were soaked for $4 \mathrm{hr}$ in aerated $\mathrm{GA}_{3}$ solutions as well as control. The treated seeds were sown on

Copyright: $\odot$ The authors. This article is open access and licensed under the terms of the Creative Commons Attribution License (http://creativecommons.org/licenses/by/4.0/) which permits unrestricted, use, distribution and reproduction in any medium, or format for any purpose, even commercially provided the work is properly cited. Attribution - You must give appropriate credit, provide a link to the license, and indicate if changes were made. 
$10^{\text {th }}$ April in the experimental field at the spacing of $50 \times 50 \mathrm{~cm}$. The recommended doses of manures and chemical fertilizers were added following the recommendation of the Ministry of Agriculture, Libya. Throughout the cropping period, all the cultural practices were carried out at typical intervals with the necessity of plant. The plant samples were collected for determination growth, flowering parameters as well as yield and its components.

\section{Growth Parameters}

Ten cucumber plants were randomly chosen from the middle part of each experimental plot at 30 days from sowing (DFS), leaving two rows from each side to avoid border effects. Epicotyl length $(\mathrm{cm})$, alternatively, plant height at flowering and at the end of the experiment as well as a branches number per plant was determined.

\section{Flowering Parameters}

Flowering date, deliberate as the number of days from planting until the appearance of the first flower, the first pistillate flower as well as the percentage of pistillate and staminate flowers were recorded.

\section{Yield and its Components}

Harvesting was done based on the marketable maturity index. The harvesting was done by hand pickings at regular intervals from 55 days from sowing. Five plants were tagged arbitrarily in every treatment for recording the observations on the following parameters; fruit number per plant, mean fruit length $(\mathrm{cm})$, mean fruit weight, and total yield (ton/hectare).

\section{Statistical Analysis}

The data were analyzed follow Analysis of Variance (ANOVA) method and mean separations were adjusted by the Multiple Comparison tests [14] using the statistical computer programme MSTAT-C v.1.2. Means were compared by using the LSD test at $5 \%$ level of significance.

\section{RESULTS AND DISCUSSION}

\section{Growth Parameters}

All growth parameters were variable influenced by the application of $\mathrm{GA}_{3}$ concentration (Table, 1; Figure, 1). The greatest epicotyls length (37\%), plant height during flowering $(80 \%)$ and plant height at the end of the experiment $(33 \%)$ was recorded with an application of $10 \mu \mathrm{g} / \mathrm{ml} \mathrm{GA}_{3}$; meanwhile,

Table 1: Variance analysis of some growth characters for "Alpha Beta" cucumber cultivar under the treatment with different concentrations of gibberellin $\left(\mathrm{GA}_{3}\right)$

\begin{tabular}{lcccc}
\hline Source & $\begin{array}{c}\text { Epicotyl } \\
\text { length }\end{array}$ & $\begin{array}{c}\text { Plant height } \\
\text { during } \\
\text { flowering }(\mathrm{cm})\end{array}$ & $\begin{array}{c}\text { Plant height at } \\
\text { the end of the } \\
\text { season }(\mathrm{cm})\end{array}$ & $\begin{array}{c}\text { Number } \\
\text { of plant } \\
\text { branches }\end{array}$ \\
\hline Rep. & 0.084 & 358.923 & 6.392 & 0.083 \\
GA3 Treat & & & & \\
$\mathrm{A}^{1}$ vs. others & $0.816^{* * *}$ & $446.195^{* *}$ & $221.018^{*}$ & 0.284 \\
$\mathrm{~B}^{2}$ vs. C C $^{3} \mathrm{D}^{4}$ & $1.212^{* * *}$ & $467.160^{* *}$ & $1068.760^{* * *}$ & $3.294^{* *}$ \\
C vs D & 0.12 & $211.939^{*}$ & 217.202 & 0.735 \\
Error & 0.035 & 27.014 & $25.812^{*}$ & 0.211 \\
\hline
\end{tabular}

* Significance at significant at level of $<0.05, * *$ significance at significant level $<0.01, * * *$ significance at significant level $<0.001$

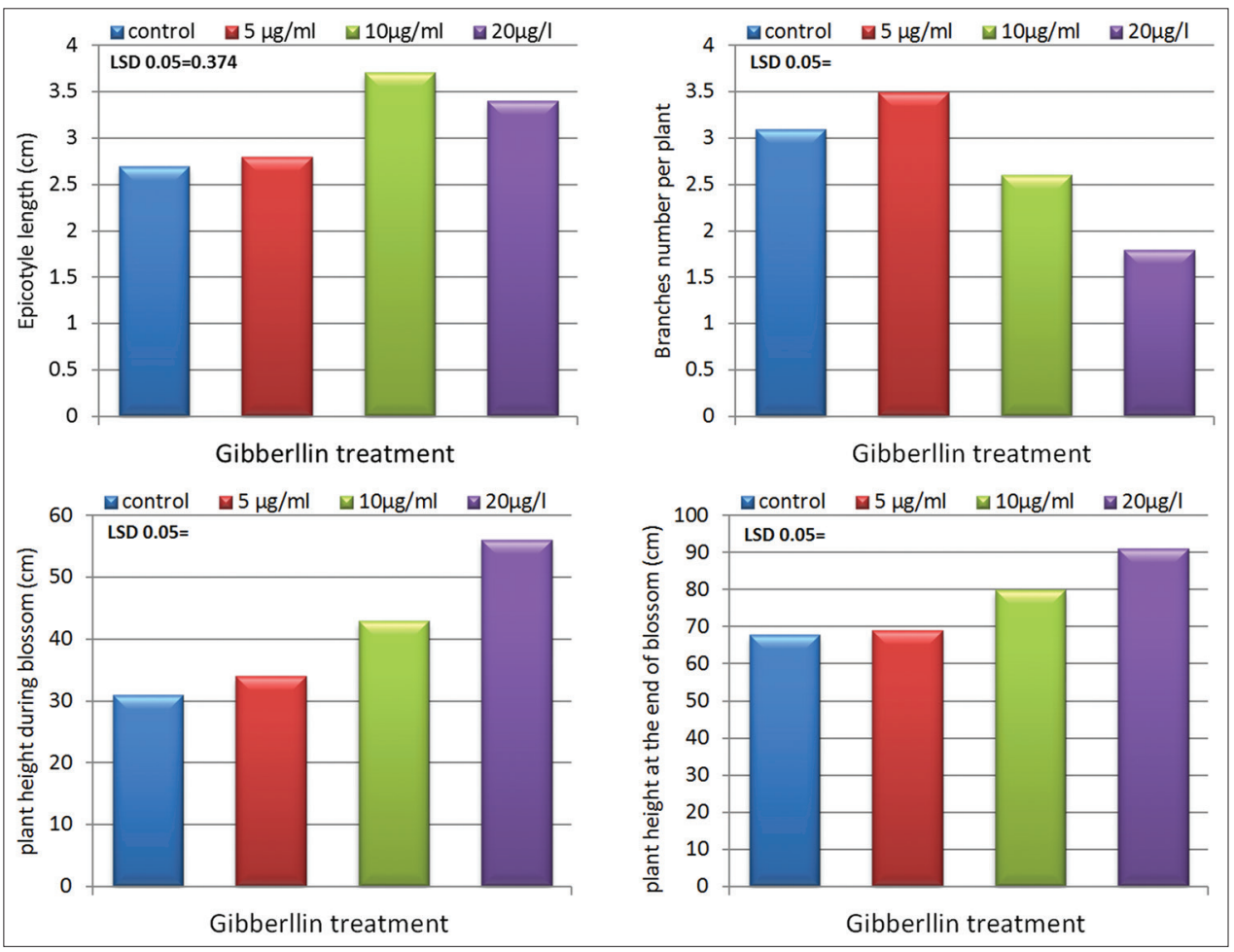

Figure 1: Effect of different concentrations of $\mathrm{GA}_{3}$ on growth attribute of cucumber plants 
the maximum branch number per plant (12\%) was obtained by application of $5 \mu \mathrm{g} / \mathrm{ml} \mathrm{GA}$, as relative to untreated control plants or the other GA concentration.

There are numerous reports showing that $\mathrm{GA}_{3}$ promote the growth of intact plants $[5,8,15,16]$. In this concern, $[10,11]$ found that the exogenous application of $\mathrm{GA}_{3}$ concentration on cucumber plants significantly increased growth parameter and seed germination compared the treatment of the control. The encouragement on growth either in terms of a boost in the epicotyls length and plant height has been thought to be by rising plasticity of the cell wall afterward hydrolysis of starch to sugars that lowers the water potential of cells, leading to the entrance of water into the cell causing elongation. These osmotically driven responses under the influence of $\mathrm{GA}_{3}$ might have recognized to rise in photosynthetic activity, accelerated translocation and efficiency of utilizing photosynthetic products, so resulting in improved cell elongation and rapid cell division in the growing portion [17].

\section{Flowering Characters}

Data presented in Table (2) and figure (2) showed that flowering behavior in cucumber was influenced by various doses of $\mathrm{GA}_{3}$. Among all the treatments, $10 \mu \mathrm{g} / \mathrm{ml}$ was found to be most effective in reducing number of days required for appearance of first flower formation, which followed by $5 \mu \mathrm{g} / \mathrm{ml}$, and $20 \mu \mathrm{g} / \mathrm{ml}$ GA, while maximum time taken for flowering was observed in control. Similarly, the minimum number of the male flower was produced in plants sprayed with $10 \mu \mathrm{g} / \mathrm{ml}$. The maximum female flowers number was examined in the treatment of $10 \mu \mathrm{g} / \mathrm{ml}$ GA, while minimum numbers of female flowers were counted under the control condition.

Exogenous application of GAs has been reported in many plants $[5,8,9,18,19]$. Early flowering of treated plants, possibly owing to stimulation of tendency of femaleness in the plant resulted from the early induction of flowers $[5,8]$ and contribute an extremely vital function in the regulation of flowering [20-23].

These results are owing to the genetic factors related to cultivar and environmental conditions during flowering in addition to the plant hormonal balance where genetically there are monoecious, gynoecious, and romonoecious and hermaphrodite species [24]. [25] indicated that there are two major genes that control sex expression in cucumber which are $\mathrm{M}$ "gives pistillate flowers in its existing form $(\mathrm{M})$ and give hermaphrodite flowers in its recessive form $(\mathrm{m})$ " and F (prevailing over $\mathrm{M}$ gene)

Table 2: Variance analysis of some flowering characters for "Alpha Beta" cucumber cultivar under the treatment with different concentrations of gibberellin $\left(\mathrm{GA}_{3}\right)$

\begin{tabular}{|c|c|c|c|c|}
\hline Source & $\begin{array}{c}\text { Flowering } \\
\text { date }\end{array}$ & $\begin{array}{l}\text { First pistillate } \\
\text { flower node }\end{array}$ & $\begin{array}{c}\text { Pistillate } \\
\text { flower (\%) }\end{array}$ & $\begin{array}{l}\text { Staminate } \\
\text { flower (\%) }\end{array}$ \\
\hline $\begin{array}{l}\text { Rep. } \\
\text { GA3 Treat }\end{array}$ & 5.083 & 1.083 & 0.003 & 0.446 \\
\hline$A^{1}$ vs. others & $28.444 * * *$ & $5.444 * * *$ & 0.002 & 9.849 \\
\hline$B^{2}$ vs. $C^{3} \& D^{4}$ & $3.555^{*}$ & 0.222 & $0.007^{*}$ & 77.211 ** \\
\hline$C$ vs $D$ & $16.667 * * *$ & 0.666 & 0.001 & 4.167 \\
\hline Error & 0.306 & 0.194 & 0.001 & 4.146 \\
\hline
\end{tabular}

*Significance at significant at level of $<0.05, * *$ significance at significant level $<0.01, * * *$ significance at significant level $<0.001$
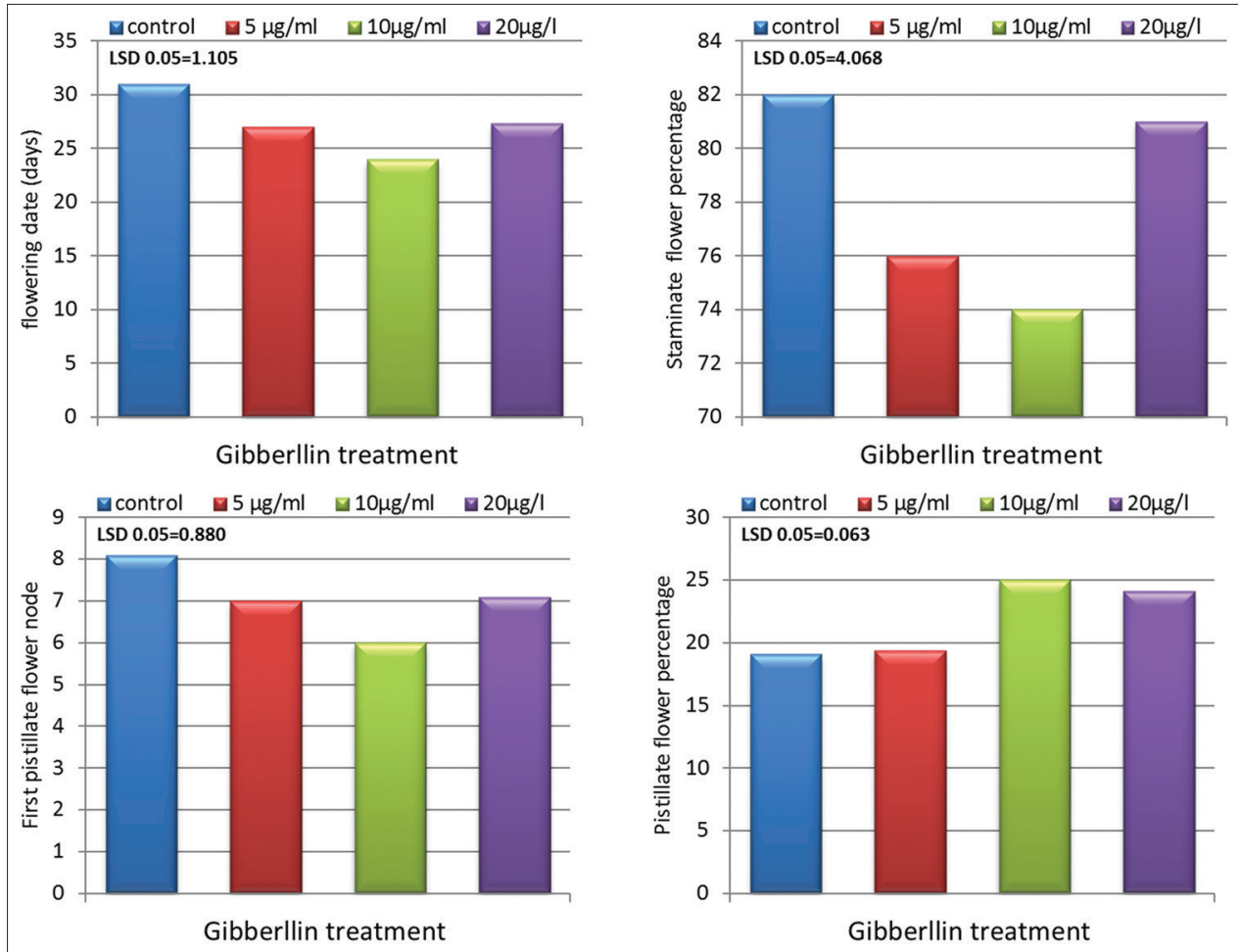

Figure 2: Effect of different concentrations of $\mathrm{GA}_{3}$ on a flowering attribute of cucumber plants 
"it gives pistillate flower in its prevailing form (F), and gives staminate flowers in recessive form (f)", and so phenotypic genetic structures $\mathrm{M}-\mathrm{F}-, \mathrm{M}-\mathrm{ff}, \mathrm{mmff}$, and $\mathrm{mmF}$ - pistillate plants, single-sex and single-dwelling plants, both masculine and hermaphrodite plants, and masculine plants correspondingly. Consistent with the impact of environmental factors on the sex ratio of cucumber it was found that the long day and relatively high temperatures increase the number of staminate flowers over the number of pistillate flowers on the plant, and vice versa, the short day and the moderate heat increase the number of pistillate flowers compared to the number of staminate flowers on plants [26].GA reduced the male flower initiation with the most favorable doses in the current investigation that might be owing to the reality that they are at the optimum level known to reduce the mobilization of photosynthates. Comparable results were also previously indicated by $[5,8,27]$.

\section{Yield and Yield Attributing Parameters}

Data pertaining from Table (3) and Figure (3) reported that the diverse doses of $\mathrm{GA}_{3}$ application were given considerable influences throughout the experimental year. In the current table and figure data obviously designate that $10 \mu \mathrm{l} / \mathrm{ml} \mathrm{GA}_{3}$ was significantly enhanced concerning yield contributing parameters with the judgment of other doses, while lower yield was recorded under control treatment.

The most important enhancement in fruit formation might be owing to $\mathrm{GA}_{3}$ increases the metabolic activity of plant that resulted in augmentation of reproductive phase in cucumber and increased the yield and its components. These results are in close agreement with the conclusion of $[5,8,28]$. In this concern, [11] found that treatment of cucumber plants with GA increased yield and improved its components as well as shortened the fruit maturation period growth, s.

It was found that the treatment with effective concentration of $\mathrm{GA}_{3}(10 \mu \mathrm{g} / \mathrm{ml})$ leads to an increase in cucumber yield, this increase may be attributed to several reasons reported by [29]; (a) treatment with $\mathrm{GA}_{3}$ concentration at $10 \mu \mathrm{g} / \mathrm{ml}$ produced a high number of pistillate flowers $(80.4 \%)$ relative to the rest of the treatments including the treatment of the control that produced $75 \%$ staminate flowers, this provides a superior chance to give a big quantity of elevated dynamic pollen grains that increases the occasion of achievement of the excellent fertilization for pistillate flowers, (b) the effect of $\mathrm{GA}_{3}$ treatment on the vitality and the quantity of pollen grains and consequently excellent fruits setting, (c) GA motivatesynthesis of protein, RNA, DNA,

Table 3: Variance analysis of yield and its components for "Alpha Beta" Cucumber cultivar under the treatment with different concentrations of gibberellin $\left(\mathrm{GA}_{3}\right)$

\begin{tabular}{lcccc}
\hline Source & $\begin{array}{c}\text { Number of } \\
\text { fruits/plant }\end{array}$ & $\begin{array}{c}\text { Mean fruit } \\
\text { weight }(\mathrm{g})\end{array}$ & $\begin{array}{c}\text { Mean fruit } \\
\text { length }(\mathrm{cm})\end{array}$ & $\begin{array}{c}\text { Total } \\
\text { crop (ton/ha) }\end{array}$ \\
\hline Rep. & 2.333 & 2282.6 & 0.931 & 1.433 \\
GA3 Treat & & & & \\
A $^{1}$ vs. others & 0.694 & 462.25 & 0.538 & 0.343 \\
B $^{2}$ vs. C ${ }^{3} \& D^{4}$ & 0.222 & 180.5 & $5.335^{* *}$ & 0.089 \\
C vs D & $6.000^{* * *}$ & $5104.167^{* * *}$ & $15.360^{* * *}$ & $1.228^{* *}$ \\
Error & 0.222 & 158.14 & 0.399 & 0.095 \\
\hline
\end{tabular}

* Significance at significant at level of $<0.05, * *$ significance at significant level $<0.01, * * *$ significance at significant level $<0.001$

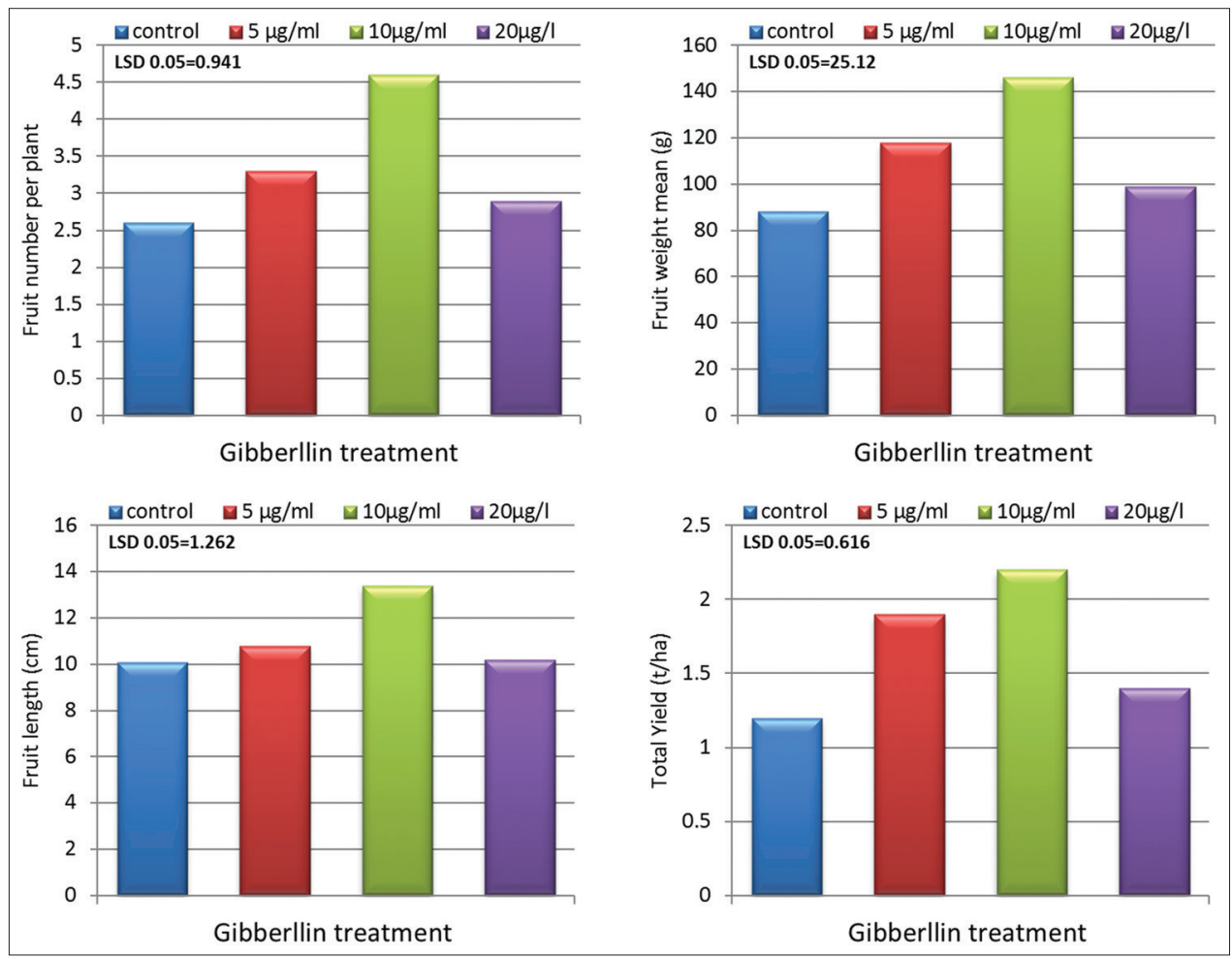

Figure 3: Effect of different concentrations of $\mathrm{GA}_{3}$ on yield and its components of cucumber plants 
ribose and multi-ribose duplication, that have a encouraging effect on the flowers production, pollination, fertilization and fruit setting; (d) $\mathrm{GA}_{3}$ stimulates the enzymatic activity, that has a large effect on the accretion of nutrients in crops, particularly with the advanced plant ages and (e) $\mathrm{GA}_{3}$ boost the permeability of the cells plasma membrane and so facilitate the absorption and utilization of nutrients and also facilitate the transmission of metabolic products.

\section{CONCLUSION}

On the basis of an outcome obtained from the current investigation concluded that the impact of $\mathrm{GA}_{3}$ on growth, flowering and yield in cucumber was giving considerable impact as compared to untreated one. Amongst all the treatment, application of $10 \mu \mathrm{g} / \mathrm{ml} \mathrm{GA}_{3}$ was established to the majority appropriate for improving growth, flowering performance, and fruit yield.

\section{AUTHOR CONTRIBUTION}

The author designed and conducts the experiment as well as writes the manuscript

\section{ACKNOWLEDGMENT}

I would be gratefully acknowledges Dr. Saad Farouk Mohamed Hussien (Faculty of Agriculture, Mansoura University, Egypt) for his helpful insights and critical review of the first draft of this manuscript as well as corrections and suggestions for the English language.

\section{REFERENCES}

1. Mukherjee PK, Nema NK, Maity N, Sarkar BK. Phytochemical and therapeutic potential of cucumber. Fitoterapia. 2013;84:227-36.

2. Abu-Reidah I, Arráez-Román D, Quirantes-Piné R, Fernández-Arroyo S, Segura-Carretero A, Fernández-Gutiérrez A. HPLC-ESI-Q-TOF-MS for a comprehensive characterization of bioactive phenolic compounds in cucumber whole fruit extract. Food Research International. 2012; 46:108-117.

3. Hooda, R. Antiwrinkle herbal drugs. Journal of Pharmacognosy and Phytochemistry. 2015; 4(4): 277-281.

4. Lopes L, Speretta F, Bentley M. Enhancement of skin penetration of vitamin $\mathrm{K}$ using monoolein-based liquid crystalline systems. European Journal of Pharmaceutical Sciences. 2007; 32(3):209-215.

5. Dalai S, Singh MK, Kumar M, Singh KV, Kumar V. Growth, flowering and yield of cucumber (Cucumus sativus $L$.) as influenced by different levels of NAA and $\mathrm{GA}_{3}$. J. Plant Development Sciences. 2016; 8(9):445-450.

6. Maria $\mathrm{CM}$, Alvarez J. The effects of temperature on pollination and pollen tube growth in muskmelon (Cucumis melo L.). Scientia Horticulturae. 1988; 36 (3-4): 173-181.

7. Birader G, Navalagatti CM Effect of plant growth regulators on physiology and quality in bitter gourd (Momor dicacharantia). M.Sc. Thesis, University of Agricultural Sciences. Dharwad. 2008.

8. Dalai S, Singh MK, Singh KV, Kumar M, Malik S, Kumar V. Effect of foliar application of GA3 and NAA on growth, flowering yield and yield attributes of cucumber (Cucumus sativus L.). Annals of Horticulture.
2015; 8(2): 181-194. DOI:10.5958/0976-4623.2015.00014.6

9. Sumanasiri H, Krishnarajah SA, Eeswara JP. Effect of gibberellic acid on growth and flowering of Henckelia humboldtianus Gardner (Ceylon Rock Primrose). Sci. Hortic. 2013; 159, 29-32.

10. Al-Sahil AA. Effect of gibberellic and salicylic acids pre-soaking seed germination, attributes of cucumber (Cucumis sativus L.) under induced salt stress. Cercetari Agronomics in Moldova. 2016; 1(165):99-109.

11. Pal P, Yadav K, Kumar K, Singh N. Effect of gibberellic acid and potassium foliar sprays on productivity and physiological and biochemical. Journal of Horticultural Research. 2016; 24(1): 93-100. DOI: 10.1515/johr-2016-0011.

12. Hilli JS, Vyakarnahal BS, Biradar DP, Ravi H. Effect of growth regulators and stages of spray on growth, fruit set and seed yield of ridge gourd (Luffa acutangula L. Roxb). Karnataka Journal of Agricultural Sciences. 2010; 23(2): 239-242.

13. Wang QM, Zeng GW. Morphological and histo-chemical study on sex differentiation in Momor dicacharantia. Journal of Zhejiang Agriculture University. 1997; 23: 149-153.

14. Norman GR, Streiner DL. PDQ Statistics, $3^{\text {rd }}$ Ed. Bc Deckker Inc., London. 2003.

15. Sure S, Arooie H, Azizi M. Effect of $\mathrm{GA}_{3}$ and Ethephon on sex expression and oil yield in medicinal pumpkin (Cucurbita pepo var. Styriaca). International Journal of Farming and Allied Sciences. 2013; 2 (9): 196-201.

16. Imamsaheb SJ, Hanchinmani CN. Effect of different levels of fertilizers and growth regulators on growth, yield and economics of bitter gourd under north-eastern transition zone, Plant Archives. 2014;14(2): 871-874

17. Sargent JA. The penetration of growth regulators into leaves. Annual Review of Plant Physiology. 1965;16(1):1-2.

18. Jadav RG, Patel TV, Parmar AB, Saiyad MY. Sex modification of cucumber vegetable through PGRs. Journal of Pure and Applied Science. 2010;18:13-14

19. Lu SJ. The Interspecific crossing between sectional species or intersectional species of kalanchoe. Master Dissertation. National Chung Hsing University, Taichung, Taiwan. 2013.

20. Sgamma T. Juvenility. In: $2^{\text {nd }}$ ed. In: Thomas B, Murphy DJ, Murray BG (Eds.), Encyclopedia of Applied Plant Sciences, vol. 1. Academic Press, California, pp. 437-441. 2017.

21. Erwin J. Factors affectingflowering in ornamental plants. In: Vainstein, A. (Ed.), Breeding for Ornamental: Classical and Molecular Approaches. Kluwer Academic Publishers, Boston, pp. 7-48. 2002.

22. Kulikowska-Gulewska H, Majewska M, Kopcewicz J. Gibberellins in the control of photoperiodic flower transition in Pharbitis nil. Physiologia Plantarum. 2000;108(2):202-207

23. Wijayanti L, Fujioka S, Kobayashi M, Sakurai A. Involvement of abscisic acid and indole-3-acetic acid in the flowering of Pharbitis nil. Journal of plant growth regulation. 1997;16(2):115-119.

24. Saito S, Fujii N, Miyazawa Y, Yamasaki S, Matsuura S, Mizusawa H, Fujita Y, Takahashi H. Correlation between development of female flower buds and expression of the CS-ACS2 gene in cucumber plants. Journal of Experimental Botany. 2007;58(11):2897-2907.

25. Kubicki B. Investigation of sex determination in cucumber (Cucumis sativus L.). Genetica Polonica. 1969;10:69-143.

26. Perl-Treves R. Male to female conversion along the cucumber shoot: approaches to studying sex genes and floral development in Cucumis sativus. In: Sex determination in plants-Ainsworth CC, ed. (1999) Oxford: BIOS Scientific Publishers Ltd. 189-215.1999.

27. Chovatia RS, Ahlawat TR, Kavathia YA, Jivani LL, Kaila DC. Effect of plant growth regulators on vegetative, flowering and yield of bitter gourd cv. Priya. Indian Journal of Horticulture. 2010; 67: 254-256.

28. Kasim ATM, Abd El-hameid AM, El-Greadly NHM. A comparison study on the effect of some treatments on earliness, yield and quality of globe artichoke (Cynara scolymus L.). Research Journal of Agriculture and Biological Science. 2007; 3(6): 695-700.

29. Evins WH, Varner JE. Hormonal control of polyribosome formation in barley aleurone layers. Plant Physiology. 1972; 49: 348-352. 